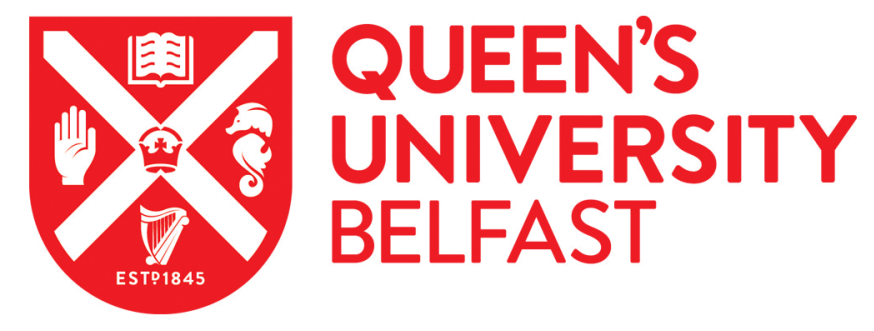

\title{
Severe Vitamin E deficiency modulates airway allergic inflammatory responses in the murine asthma model
}

Lim, Y., Vasu, V. T., Valacchi, G., Leonard, S., Aung, H. H., Schock, B., Kenyon, N. J., Li, C. S., Traber, M. G., \& Cross, C. E. (2008). Severe Vitamin E deficiency modulates airway allergic inflammatory responses in the murine asthma model. Free Radical Research, 42(4)(4), 387-396. https://doi.org/10.1080/10715760801976600

Published in:

Free Radical Research

Queen's University Belfast - Research Portal:

Link to publication record in Queen's University Belfast Research Portal

\section{General rights}

Copyright for the publications made accessible via the Queen's University Belfast Research Portal is retained by the author(s) and / or other copyright owners and it is a condition of accessing these publications that users recognise and abide by the legal requirements associated with these rights.

Take down policy

The Research Portal is Queen's institutional repository that provides access to Queen's research output. Every effort has been made to ensure that content in the Research Portal does not infringe any person's rights, or applicable UK laws. If you discover content in the Research Portal that you believe breaches copyright or violates any law, please contact openaccess@qub.ac.uk. 


\title{
Severe Vitamin E deficiency modulates airway allergic inflammatory responses in the murine asthma model
}

\author{
YUNSOOK LIM ${ }^{1,2}$, VIHAS T. VASU ${ }^{1}$, GIUSEPPE VALACCHI ${ }^{1,3}$, SCOTT LEONARD $^{4}$, HNIN \\ HNIN AUNG ${ }^{1}$, BETTINA C. SCHOCK ${ }^{1,5}$, NICHOLAS J. KENYON ${ }^{1}$, CHIN-SHANG LI ${ }^{6}$, MARET \\ G. TRABER ${ }^{4}$, and CARROLL E. CROSS ${ }^{1}$ \\ ${ }^{1}$ Department of Internal Medicine, Center for Comparative Lung Biology and Disease, School of \\ Medicine, UC Davis, Davis, CA 95616, USA \\ ${ }^{2}$ Department of Food and Nutrition, Institute of Human Ecology, Kyung Hee University, Seoul \\ 130-701, Korea \\ ${ }^{3}$ Department of Physiology, University of Siena, Italy \\ ${ }^{4}$ Department of Nutrition and Food Management, Linus Pauling Institute, Oregon State University, \\ Corvallis, OR 97331, USA \\ ${ }^{5}$ Respiratory Research Group, Department of Medicine, Queens University, Belfast, UK \\ ${ }^{6}$ Division of Biostatistics, Department of Public Health Sciences, School of Medicine, UC Davis, \\ Davis, CA 95616, USA
}

\begin{abstract}
Allergic asthma is a complex immunologically mediated disease associated with increased oxidative stress and altered antioxidant defenses. It was hypothesized that $\alpha$-tocopherol $(\alpha-\mathrm{T})$ decreases oxidative stress and therefore its absence may influence allergic inflammatory process, a pathobiology known to be accompanied by oxidative stress. Therefore, selected parameters of allergic asthma sensitization and inflammation were evaluated following ovalbumin sensitization and re-challenge of $\alpha$-T transfer protein (TTP) knock-out mice (TTP ${ }^{-/-}$) that have greatly reduced lung $\alpha$-T levels (e.g. $<5 \%$ ) compared to their litter mate controls $\left(\mathrm{TTP}^{+/+}\right)$. Results showed that severe $\alpha$-T deficiency result in a blunted lung expression of IL-5 mRNA and IL-5 protein and plasma IgE levels compared with $\mathrm{TTP}^{+/+}$mice following immune sensitization and rechallenge, although lung lavage eosinophil levels were comparable in both genomic strains. It is concluded that the initial stimulation of immune responses by the $\mathrm{TTP}^{-/-}$mice were generally blunted compared to the $\mathrm{TTP}^{+/+}$mice, thus diminishing some aspects of subsequent allergic inflammatory processes.
\end{abstract}

\section{Keywords}

Eosinophils; allergic inflammation; asthma; cytokines; IgE; vitamin E

\section{Introduction}

Allergic sensitization in the respiratory tract and its accompanying inflammatory-immune mediated responses represent the proximate cause of the airflow limitation characterizing

(c) 2008 Informa UK Ltd.

Correspondence: Carroll E Cross, MD, University of California Davis, CCRBM, Genome and Biomedical Sciences Facility, 451 East Health Sciences Drive, Davis, CA 95616, USA. Tel: (530) 752-6305. Fax: (530) 752-8632. cecross@ ucdavis.edu. 
allergic asthma. The operative immunological pathways involve a complex interaction of mediators, signalling pathways and cellular responses including the proliferation and activation of sub-type $\mathrm{Th} 2 \mathrm{CD} 4^{+}$lymphocytes, IgE production and eosinophilic airway infiltration [1]. Most airway diseases, including asthma, are related to inflammatory processes and these processes have been shown to be accompanied by oxidative stress [2]. These evidences have thus given rise to proposals that antioxidants may represent a logical therapeutic approach [3-5].

Evidence of oxidative stress [3-9] and the reduction of protective nutritional [10,11] and some [12-14], but not all [15], enzymatic antioxidant defenses in asthmatics is particularly intriguing. There has been considerable interest in the possible modulation of asthma by antioxidants $[3,8,16]$. These and other observational studies suggesting possible associations between asthma incidence and severity and dietary intake of antioxidant micronutrients have given rise to clinical trials utilizing supplemental administration of the major hydrophilic and lipophilic antioxidants, vitamins $\mathrm{C}$ and $\mathrm{E}$, respectively. However, these oral supplement trials have thus far failed to demonstrate overall convincing beneficial effects in asthma $[8,17,18]$.

The experimental rodent model of allergic asthma, utilizing the surrogate allergen, ovalbumin (OVA), has been extensively studied $[19,20]$. Although several investigators have used this model to evaluate the effects of nutritional antioxidants to modulate the ensuing allergenmediated airway immunological responses, the results have been variable [21-23]. A recent well conducted study utilizing the rodent animal model showed that vitamin E administration could ameliorate both the oxidative stress and immunophysiologic array of allergic respiratory tract responses, including most notably antigen-induced early IL-5 increases and airway hyperreactivity [24]. In elderly human populations administrations of vitamin $E$ have been reported to increase immune responses $[25,26]$. In another large random human study $(n=2633)$ dietary levels of vitamin $\mathrm{E}$ were inversely associated with serum IgE concentrations and the frequency of allergen sensitization [27].

In order to further test the hypothesis that allergic inflammatory processes can be modulated by vitamin E, we designed a study of select parameters of allergic sensitization and inflammation utilizing the standard OVA sensitized allergic mouse model in a strain with a genetic absence of the $\alpha$-tocopherol $(\alpha-\mathrm{T})$ transfer protein $\left(\mathrm{TTP}^{--}\right)$. These mice are unable to incorporate absorbed $\alpha$-T into liver secreted VLDL [28] and exhibit less than 5\% of plasma and lung tissue $\alpha$-T levels compared to their wild-type littermate controls (TTP ${ }^{+/+}$) [29]. The results of this study have been partly presented in the form of an abstract [30].

\section{Material and methods}

\section{Animals and diet}

C57BL/6 male mice with a deletion of the TTP gene $\left(\mathrm{TTP}^{-/-}\right)$and their $\mathrm{TTP}^{+/+}$littermates were generated from our own colony. Originally, the deletion of the TTP gene was performed in $129 \mathrm{~Sv} / \mathrm{Jae}$ background mice [31]. One hundred and twenty-nine Sv/Jae mice with deletion of TTP were bred with C57BL/6 mice over 10 generations. Animals were randomly screened for the absence of viral and respiratory pathogens and housed in polycarbonate shoebox type cages with wire tops in a room maintained at $20^{\circ} \mathrm{C}$ and $60-70 \%$ humidity on a $12 \mathrm{~h} \mathrm{light/dark}$ schedule and with ad libitum access to water and standard rodent chow diet (PicoLab® Mouse Diet 20,5058, containing $66 \mathrm{IU}$ dl $\alpha$-tocopheryl acetate per $\mathrm{kg}$ diet, roughly equivalent to 30 $\mathrm{mg} 2 R$ - $\alpha$-tocopherol). $\mathrm{TTP}^{-/}$mice were bred by mating male and female heterozygous $\mathrm{TTP}^{+/-}$mice for the gene deletion because $\alpha$-T deficiency causes foetal resorption in female $\mathrm{TTP}^{-/-}$mice. The offspring were genotyped using a specific primer for TTP and the genotype of each animal was confirmed by liver TTP protein expression by Western Blot analysis using 
a specific antibody against the TTP protein [29]. Protocols for the care and use of animals were approved by the UC Davis Animal Use and Care Committee.

\section{Ovalbumin exposure}

Procedures for sensitization and exposure of mice to OVA aerosol have been described in detail elsewhere [20,32]. Briefly, mice, 6-8 weeks old were systemically sensitized to OVA (10 $\mu \mathrm{g} /$ $0.1 \mathrm{ml}$ chicken egg albumin, ovalbumin, grade V, 98\% pure, Sigma, St. Louis, MO) by intraperitoneal (i.p.) injection on days 0 and 14. Exposures to aerosolized OVA (10 $\mathrm{ml}$ of 10 $\mathrm{mg}$ OVA $/ \mathrm{ml} 1 \%$ PBS solution) were commenced on day 28 after the first i.p. OVA injection for 30 min per day for 3 consecutive days; $1 \%$ PBS solution was used for the control group. Nebulization was performed in a plastic chamber connected to a side-steam nebulizer (Invacare Corporation, Elyria, OH), ProNeb compressor nebulizer (Pari, Richmond) and passport Compressor (Invacare, Sanford, FL) [20,32].

\section{Plasma, broncho-alveolar lavage (BAL) and tissue harvest}

Immediately following the third exposure mice were euthanized with pentobarbital (i.p.) and blood was collected by cardiac puncture in heparinized tubes. Plasma was obtained by centrifugation and stored at $-80^{\circ} \mathrm{C}$. After blood collection, lungs were lavaged twice with $1 \mathrm{ml}$ of PBS (pH 7.4) as previously described [29]. Collected BAL fluid was immediately placed on ice and centrifuged at $500 \times g$. For differential cell analysis, an aliquot $(10 \mu \mathrm{l})$ of BAL cell suspension was cyto-centrifuged and stained with Wright-Giemsa stain (Diff-Quik, Baxter Scientific Products, McGrow Park, IL). The BAL supernatants were used for the measurement of cytokines.

\section{Plasma and tissue levels of $\alpha-T$ and $\mathrm{y}$-tocopherol $(\mathrm{Y}-\mathrm{T})$}

Plasma, liver and lung $\alpha$-T and $\gamma$-T concentrations were determined using high pressure liquid chromatography (HPLC) with electrochemical detection as previously described [33].

\section{Plasma IgE levels}

Mouse plasma IgE was measured using a standard sandwich ELISA kit purchased from BD Pharmingen (San Diego, CA). Briefly, $100 \mu \mathrm{l}$ of purified anti-mouse IgE, diluted to $2 \mu \mathrm{g} / \mathrm{ml}$ in PBS, was used to coat a 96-well ELISA plate. Plates were coated overnight at $4{ }^{\circ} \mathrm{C}$ and then washed three times with PBS/Tween $(0.05 \%) ; 200 \mu \mathrm{l}$ of $10 \%$ foetal calf serum (FCS)/PBS was added to each well for $1 \mathrm{~h}$ at room temperature. After three washes with PBS/Tween, $100 \mu \mathrm{l}$ of sample or purified mouse IgE standard diluted in 10\% FCS were added to each well and incubated for $1 \mathrm{~h}$. After washing, biotinylated anti-mouse $\operatorname{IgE}(2 \mu \mathrm{g} / \mathrm{ml})$ was added for $1 \mathrm{~h}$; $100 \mu \mathrm{l}$ of diluted strepavidin-horseradish peroxidase (1:1000 in 10\% FCS) was then added for $30 \mathrm{~min}$. After a final three washes, $100 \mu \mathrm{l}$ of an equal mixture of $30 \% \mathrm{H}_{2} \mathrm{O}_{2}$ and tetramethylbenzidine (TMB, BD Pharmingen) was added for 10-20 min. The reaction was stopped with $50 \mu \mathrm{l}$ of $1 \mathrm{~m} \mathrm{H}_{3} \mathrm{PO}_{4}$ and the plate was read immediately with a microplate reader at $450 \mathrm{~nm}$.

\section{Cytokine concentrations}

Plasma and BAL concentrations of cytokines (IL-4, IL-5, TNF- $\alpha$, IFN- $\gamma$ and sICAM) were measured using commercially available ELISA assays, (Quantikine R\&D system, MN).

\section{Lung gene expression of inflammatory markers}

These methods have been described in detail [29]. Briefly, RNA from lung was isolated by extraction into Trizol following the manufacturer's instructions and cDNA was synthesized from $5 \mu \mathrm{g}$ total RNA as in reverse transcript PCR. Gene-specific primers were designed with 
use of Primer Express 1.0 software (Applied Biosystems) and glyceraldehyde-3-phosphate dehydrogenase (GAPDH) mRNA levels which were used to normalize the gene expression level. Real-time PCR was carried out with SYBR Green I Master Mix (Applied Biosystems) reagent. Real time PCR values were determined by reference to a standard curve that was generated by real time PCR amplification of serially diluted cDNAs for each genes. A duplicate reaction was carried out for each sample. Quantitative PCR assay was performed with genespecific double-labelled fluorescent probes and sets of specific primers in an ABI PRISM 7700 Sequence detection system (PE Applied Biosystems). Reverse transcriptase reactions were incubated at $50^{\circ} \mathrm{C}$ for $30 \mathrm{~min}$ and after inactivation of reverse transcriptase at $95^{\circ} \mathrm{C}$ for $12 \mathrm{~min}$, 40 cycles of amplification were carried out with denaturation at $95^{\circ} \mathrm{C}$ for $15 \mathrm{~s}$ each and both annealing and extension at $60^{\circ} \mathrm{C}$ for $1 \mathrm{~min}$ each. The sequences of primer pairs used in the experiments were as follows: TNF- $\alpha$ : (forward) GAAAAGCA AGCAGCCAACCA, (reverse) GGGCCAGTGAGTGAAAGGG, IFN- $\gamma$ : (forward) AGC TCA TCC GAG TGG TCC AC, (reverse) GCT TCC TGA GGC TGG ATT CC, ICAM-1: (forward) TGC GTT TTG GAG CTA GCG GAC CA, (reverse) CGA GGA CCA TAC AGC ACG TGC AG, IL-4: (forward) CACGGATGCGACAAAAATCA, (reverse) CTCGTTCA AAATGCC GATGA, IL-5: (forward) ACGCAGGAGGAT CACATACC, (reverse) GGCTCTCATTCACACTGCAA.

\section{Statistical analysis}

Prior to making comparisons, we used the Shapiro-Wilk test for normalizing the responsible variables of interest and the results indicated that a number of responsible variables were departed from normality. Hence, we used non-parametric analyses. For each of the response variables including $\alpha$-T and $\gamma$-T levels in plasma, liver and lung, we tested for a significant

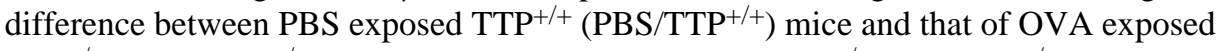

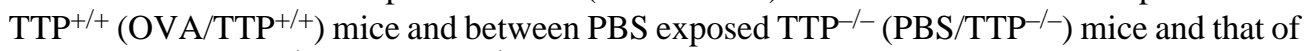
OVA exposed $\mathrm{TTP}^{-/-}\left(\mathrm{OVA} / \mathrm{TTP}^{--}\right)$mice by using the two-sided exact Wilcoxon-MannWhitney (W-M-W) test; the one-sided exact W-M-W test was used to determine whether the median of the response variable was higher in the $\mathrm{PBS} / \mathrm{TTP}^{+/+}$and OVA/TTP ${ }^{+/+}$groups compared with the PBS/TTP ${ }^{-/-}$and OVA/TTP ${ }^{-/}$groups, respectively. For the other response variables, the two-sided exact $\mathrm{W}-\mathrm{M}-\mathrm{W}$ test was used to assess whether there was a significant difference between the PBS/TTP ${ }^{+/+}$and $\mathrm{PBS} / \mathrm{TTP}^{-/-}$groups and between the OVA/TTP ${ }^{+/+}$ and OVA/TTP ${ }^{-/}$groups; we used the one-sided exact W-M-W test to evaluate whether the median of the response variable in the OVA/TTP ${ }^{+/+}$and $\mathrm{OVA}_{\mathrm{TTP}}{ }^{-/-}$groups exceeded that in the PBS/TTP ${ }^{+/+}$and PBS/TTP ${ }^{-/}$groups, respectively. A p-value $\leq 0.05$ was considered statistically significant. Summary statistics were expressed as mean \pm standard deviation (SD) and median (minimum, maximum).

\section{Results}

\section{Plasma and tissue $\alpha-T$ and $\mathrm{Y}-\mathrm{T}$ concentrations}

Plasma and tissue $\alpha-\mathrm{T}$ and $\gamma-\mathrm{T}$ concentrations in $\mathrm{TTP}^{+/+}$and $\mathrm{TTP}^{-/-}$mice exposed to aerosolized PBS or to OVA are shown in Figures 1(A-F), respectively. As expected, vitamin E concentrations were significantly lower in $\mathrm{TTP}^{-/-}$mice compared with $\mathrm{TTP}^{+/+}$mice. Baseline plasma, lung and liver r $\alpha-\mathrm{T}$ levels in $\mathrm{TTP}^{-/-}$mice were $0.8 \%, 2 \%$ and $19 \%$ of those of $\mathrm{TTP}^{+/+}$mice, respectively, while $\gamma$-T levels were $0.7 \%, 16 \%$ and $34 \%$ of those of $\mathrm{TTP}^{+/+}$ mice (Figure 1A-F) as a result of TTP gene deletion. Regardless of genotype, after OVA exposure, plasma $\alpha-\mathrm{T}$ and $\gamma$-T concentrations were not significantly different (Figure 1A and B). Liver $\alpha$-T concentrations significantly decreased $(\mathrm{p}<0.01)$ in $\mathrm{TTP}^{+/+}$mice after OVA exposure as compared to respective PBS exposed $\mathrm{TTP}^{+/+}$controls (Figure 1C), while lung $\alpha-$ $\mathrm{T}$ concentrations increased in both $\mathrm{TTP}^{+/+}$and $\mathrm{TTP}^{-/-}$mice $(\mathrm{p}<0.01$ ) (Figure 1E) after OVA exposure as compared to its respective PBS treated controls. Both liver and lung $\gamma-\mathrm{T}$ 
concentrations in $\mathrm{TTP}^{+/+}$and $\mathrm{TTP}^{-/-}$mice were unchanged after OVA challenge (Figure 1D and F).

\section{BAL cells}

BAL cells were counted and differential cell analysis was performed. Total cell numbers were significantly increased after OVA exposure in both groups of $\mathrm{TTP}^{+/+}$and $\mathrm{TTP}^{-/-}$mice $(p<$ $0.01)$ (Figure 2A). Eosinophil counts were significantly increased after OVA exposure in $\mathrm{TTP}^{+/+}$mice $(p<0.01)$ and $\mathrm{TTP}^{-/-}$mice $(p<0.05)$ as compared to respective PBS treated controls (Figure 2B). Eosinophil percentages of the BAL cells in the OVA exposed $\mathrm{TTP}^{+/+}$ and $\mathrm{TTP}^{--}$mice were significantly higher $(p<0.01)$, representing $50 \%$ and $41 \%$, respectively, as compared to PBS treated mice (Figure 2C). For the three response variables, there were no significant differences between the two genotypes. The normal lung lavage from a healthy mouse contains more that $90 \%$ alveolar macrophages [34] and our observations in the airexposed groups were consistent with this finding. The increase in inflammatory cells seen in the BAL from the OVA-exposed groups is predominantly accounted for by the increase in lung lavage eosinophils.

\section{Plasma IgE levels}

Plasma IgE levels were significantly increased after OVA exposure in $\mathrm{TTP}^{+/+}$mice $(p<0.05)$ but unchanged in $\mathrm{TTP}^{-/-}$mice (Figure 3). There were no significant differences in plasma IgE level between the two genotypes.

\section{Inflammatory mediators}

Chemokine, cytokine and adhesion molecules play important roles in the trafficking of activated immune cells into the airway during inflammatory responses and to a degree these processes are reflected in the levels of these species in both plasma and BAL fluids. Plasma IL-5 levels were not significantly increased in OVA exposed mice regardless of genotype (Figure 4A). IL-5, a cytokine related to eosinophil recruitment into airways, in BAL was significantly increased in OVA exposed $\mathrm{TTP}^{+/+}$mice $(p<0.05)$ but not in $\mathrm{TTP}^{-/-}$mice as compared to respective PBS treated controls (Figure 4B). IL-5 mRNA levels in lung homogenates of OVA exposed $\mathrm{TTP}^{+/+}$mice were significantly increased $(p<0.05)$; however, lung homogenate IL-5 mRNA levels were relatively unchanged in $\mathrm{TTP}^{-/-}$mice (Figure $4 \mathrm{C}$ ). Plasma IL-4, IFN- $\gamma$ and TNF- $\alpha$ concentrations were not different between PBS and OVA exposed mice regardless of genotype (data not shown).

TNF- $\alpha$ mRNA levels were also significantly increased in lung homogenates of OVA exposed $\mathrm{TTP}^{+/+}$mice $(p<0.01)$ (Figure 5), but BAL fluid was limited so it was not possible to determine BAL TNF- $\alpha$ protein levels (thus it is unknown if BAL TNF- $\alpha$ protein was also increased). Remarkably, lung TNF- $\alpha$ mRNA was essentially unchanged in $\mathrm{TTP}^{-/-}$mice, again demonstrating that the vitamin $\mathrm{E}$ deficient mice were relatively less responsive.

Plasma and BAL sICAM concentrations significantly increased after OVA exposure in $\mathrm{TTP}^{+/+}$mice $(p<0.05, p<0.01$, respectively); however, no significant changes were seen in lung ICAM mRNA expression (Figure 6A-C). There was no significant change in plasma and BAL sICAM levels or lung ICAM mRNA expression in OVA exposed TTP $^{-l}$. There was no significant difference between the two genotypes for any of the three response variables (Figure $6 \mathrm{~A}-\mathrm{C})$.

\section{Discussion}

The present studies have demonstrated that $\mathrm{TTP}^{-/-}$mice with greatly reduced lung $\alpha$-T levels exhibit a very significant modulation of allergic airway inflammation, as scored by both IL-5 
and $\operatorname{IgE}$ responses. It is likely that the initial stimulation to generate allergic responses in the $\mathrm{TTP}^{-/-}$mice were somewhat blunted compared to the $\mathrm{TTP}^{+/+}$mice.

\section{Allergic inflammation and vitamin $\mathrm{E}$}

It is generally accepted that $\mathrm{Th} 2 \mathrm{CD} 4^{+}$cells and their cytokine profiles, IgE and eosinophils play important roles in the pathogenesis of allergic inflammatory processes including allergic airway inflammation [1] and to a large extent these findings are well demonstrated in the OVA sensitization mouse model $[19,20,24,32]$ including those of the present report. $\alpha$-T has been reported to influence a large and diverse number of pathways that could contribute to immunologically activated inflammatory processes. These include NF- $\kappa \mathrm{B}[35,36]$ and cytokine [24,29,37] pathways, phospholipase and arachidonic pathways [38,39], mast cell activation $[40,41]$ and, importantly, in the context of the present studies, cell-mediated immunity [26,42,43] and antibody production [44] including that of $\operatorname{IgE}$ [22]. Central to the pathogenesis of allergic inflammation are antigen-specific, memory T-cell responses and antigen-specific IgE responses [1]. The present findings of $\alpha$-T related modulations of these pathways are thus compatible with numerous studies showing that $\alpha$-T plays a demonstrable role in modulating immune functions.

IgE hyperproduction to antigen sensitization has long been recognized to play a key role in the immunopathology of allergic airway inflammation $[1,22,45]$. Although the precise mechanisms of action are incompletely characterized, $\operatorname{IgE}$ has a wide spectrum of abilities to induce the production and secretion of inflammatory cytokines such as TNF- $\alpha$ and IL-6 [46]. Moreover, plasma IgE levels have been associated in some studies with the severity of allergic airway inflammation [47].

Our findings of low IgE concentrations in $\mathrm{TTP}^{-/-}$mice compared to $\mathrm{TTP}^{+/+}$mice are at variance with reports of an inverse relationship between $\alpha$-T levels and IgE production in allergic patients including asthmatics [11,47] and in an allergic asthma rodent model with a much lower range of vitamin E levels (e.g. 4:1 vs the current study of 100:1) [24], but are in concordance with reports of $\alpha$-T induced enhanced responses to immunologic stimuli in aged human populations [26,48]. Given the complexities of antigen-induced immune responses and the variability of experimental methodologies concerning dose-time relationships and endpoint scoring methodologies, it can be concluded that although evidence points to a role of $\alpha$-T in regulating IgE concentrations, the mechanisms remain obscure. Finally, the current study is compatible with those of Bando et al. [22] who have demonstrated a biphasic effect of $\alpha$-T in an allergic OVA sensitization model of systemic allergy.

Accumulation of eosinophils in the airways is multifunctional, involving eosinopoiesis, migration and diapedesis and facilitation by numerous cytokines including IL-5, chemotactic factors, adhesion molecules and proteolytic enzymes $[1,49,50]$. IL- 5 has been implicated in the development of allergic inflammation and reportedly is important in mobilizing eosinophils from the bone marrow, whereas chemokines such as eotaxin-1 may be largely responsible for the recruitment of eosinophils into respiratory tract tissues [51]. In the current study, at the time interval studied, the important Th 2 cytokine, IL-5 was significantly lower in $\mathrm{TTP}^{-/-}$mice than in $\mathrm{TTP}^{+/+}$mice, but the reductions of airway lumen eosinophil recruitment did not reach statistical significance. Although the present studies showed greatly diminished augmentations of IL-5 in the BAL of $\mathrm{TTP}^{-/-}$mice compared to $\mathrm{TTP}^{+/+}$mice, the results suggest that $\mathrm{IL}-5$ is not the only mechanism for attracting eosinophils into airway lumens, perhaps in keeping with the limited effectiveness of anti-IL-5 therapeutic strategies in human allergy [52]. In addition, TNF- $\alpha$ and ICAM levels were significantly decreased in $\mathrm{TTP}^{-/-}$mice as compared with $\mathrm{TTP}^{+/+}$mice, thus showing some consistency with the IL-5 and IgE determinations in that these pathways are also activated in allergic inflammatory responses $[1,49]$. 


\section{Pathobiological significance}

Although still incompletely understood, the mechanisms underlying the development of allergic airways inflammation, a key clinical feature of allergic asthma, have been associated with augmented Th2 $\mathrm{CD}^{+}$cytokine production and IgE elevations and have involved both sensitization and subsequent rechallenge inflammatory-immune responses. The same therapeutic intervention would thus not necessarily be expected to both of these complex processes in the same manner. For example, markedly differently effects of iNOS inhibitors have been demonstrated on allergic airway inflammation in an similar experimental murine asthma model (e.g. iNOS inhibitors showed opposite effects depending on their schedule of administration in the overall sensitization-re-challenge process) [53].

Allergic airway inflammation is a complex process involving interactions among airway epithelium, inflammatory cells including T-cells, macrophages, mast cells and eosinophils and their mediators. Vitamin E potentially influences many constituents of these complex integrated pathways of allergen sensitization and subsequent inflammatory-immune processes. In various studies vitamin $E$ has been touted to have immunostimulatory properties [48], antiinflammatory [54,55] and/or both properties [29]. In clinical studies, $\alpha$-T appeared to both decrease $\operatorname{IgE}$ levels and clinical manifestations of atopy in patients with allergic dermatitis [56] and appeared to have had a small clinical benefit in allergic rhinitis [57]. Of some relevance to the current study is a recent report of dramatic inhibition of murine allergic sensitization responses by the administration of pharmacological doses of $\gamma$-T [58,59].

The following limitations of the present study should be mentioned. These include the limited range of sensitizing and challenging antigenic doses and $\alpha$-T levels utilized, the limited postchallenge period examined, the limited range of mediators scored for endpoint analysis and the lack of patho-physiological correlations. A temporal analysis of sensitization effectiveness and post-challenge spectrum of chemokine and cytokine profiles, including such counterregulatory mediators as INF- $\gamma$ and IL-10, would have more completely characterized $\alpha$-T effect on allergen-induced airway inflammatory-immune processes in this model $[24,60]$, but was beyond the scope of the present project designed to show allergic inflammatory responses to be modulated in the $\mathrm{TTP}^{-/-}$mouse compared to their $\mathrm{TTP}^{+/+}$littermates. Finally, it is likely that the administration schedules of $\alpha$-T, like another pleuropotential biological metabolic modular, nitric oxide [53,61], effect overall allergic reactions differently at various stages of the sensitization-rechallenge cycle. The finding that $\gamma$-T administration appear to dramatically ameliorate allergic inflammation when given after antigen stimulation is relevant in this regard [58,59], possibly via mechanisms interacting with prostaglandin metabolic pathways [6264]. Although it has been shown that vitamin E administration can modulate biomarkers of oxidative stress in this model [24], it is possible that non-antioxidant vitamin E functions [65] contribute to the vitamins' modulation of allergic responses.

In summary, results from this animal study demonstrate that $\alpha$-T has complex interactions with allergic inflammatory processes. In at least the current model, $\mathrm{TTP}^{-/-}$mice with severe $\alpha$-T deficiency appear to dampen selected parameters of the early sensitization phase as compared to their $\mathrm{TTP}^{+/+}$littermates, supporting the concept that inadequate vitamin $\mathrm{E}$ levels leads to reduced immune responses.

\section{Acknowledgments}

We would like to thank Jennifer Jew for her assistance with IgE ELISA determinations. Support for this work was received from NIH Grant \#ES011985 and USDA grant \# 35200-13456 to CEC and MGT and NIH grant \# K08HL76415 to NJK. 


\section{References}

1. Umetsu DT, Dekruyff RH. Immune dysregulation in asthma. Curr Opin Immunol 2006;18:727-732. [PubMed: 17010591]

2. Cross CE, Vandervliet A, O'Neill CA, Eiserich JP. Reactive oxygen species and the lung. Lancet 1994;344:930-933. [PubMed: 7934352]

3. Bowler RP, Crapo JD. Oxidative stress in allergic respiratory diseases. J Allergy Clin Immunol 2002;110:349-356. [PubMed: 12209079]

4. Grimble, RF. Anitioxidant modulation in immune function.. In: Rimbach, G.; Fuchs, J.; Packer, L., editors. Nutrigenomics. Taylor \& Francis; New York: 2005. p. 97-122.

5. Kirkham P, Rahman I. Oxidative stress in asthma and COPD: antioxidants as a therapeutic strategy. Pharmacol Ther 2006;11:476-494. [PubMed: 16458359]

6. Dworski R, Roberts LJ 2nd, Murray JJ, Morrow JD, Hartert TV, Sheller JR. Assessment of oxidant stress in allergic asthma by measurement of the major urinary metabolite of F2-isoprostane, 15-F2tIsoP (8-iso-PGF2alpha). Clin Exp Allergy 2001;31:387-390. [PubMed: 11260149]

7. Andreadis AA, Hazen SL, Comhair SA, Erzurum SC. Oxidative and nitrosative events in asthma. Free Radic Biol Med 2003;35:213-225. [PubMed: 12885584]

8. Caramori G, Papi A. Oxidants and asthma. Thorax 2004;59:170-173. [PubMed: 14760161]

9. Fujisawa T. Role of oxygen radicals on bronchial asthma. Curr Drug Targets Inflamm Allergy 2005;4:505-509. [PubMed: 16101530]

10. Rubin RN, Navon L, Cassano PA. Relationship of serum antioxidants to asthma prevalence in youth. Am J Respir Crit Care Med 2004;169:393-398. [PubMed: 14630617]

11. Ford ES, Mannino DM, Redd SC. Serum antioxidant concentrations among U.S. adults with selfreported asthma. J Asthma 2004;41:179-187. [PubMed: 15115170]

12. De Raeve HR, Thunnissen FB, Kaneko FT, Guo FH, Lewis M, Kavuru MS, Secic M, Thomassen MJ, Erzurum SC. Decreased Cu, Zn-SOD activity in asthmatic airway epithelium: correction by inhaled corticosteroid in vivo. Am J Physiol 1997;272:L148-L154. [PubMed: 9038914]

13. Comhair SA, Bhathena PR, Dweik RA, Kavuru M, Erzurum SC. Rapid loss of superoxide dismutase activity during antigen-induced asthmatic response. Lancet 2000;355:624. [PubMed: 10696986]

14. Ghosh S, Janocha AJ, Aronica MA, Swaidani S, Comhair SA, Xu W, Zheng L, Kaveti S, Kinter M, Hazen SL, Erzurum SC. Nitrotyrosine proteome survey in asthma identifies oxidative mechanism of catalase inactivation. J Immunol 2006;176:5587-5897. [PubMed: 16622028]

15. Comhair SA, Bhathena PR, Farver C, Thunnissen FB, Erzurum SC. Extracellular glutathione peroxidase induction in asthmatic lungs: evidence for redox regulation of expression in human airway epithelial cells. Faseb J 2001;15:70-78. [PubMed: 11149894]

16. Hubbard R, Fogarty A. The developing story of antioxidants and asthma. Thorax 2004;59:3-4. [PubMed: 14694233]

17. Pearson PJ, Lewis SA, Britton J, Fogarty A. Vitamin E supplements in asthma: a parallel group randomised placebo controlled trial. Thorax 2004;59:652-656. [PubMed: 15282383]

18. Riccioni G, Barbara M, Bucciarelli T, di Ilio C, D'Orazio N. Antioxidant vitamin supplementation in asthma. Ann Clin Lab Sci 2007;37:96-101. [PubMed: 17311877]

19. Hellings PW, Ceuppens JL. Mouse models of global airway allergy: what have we learned and what should we do next? Allergy 2004;59:914-919. [PubMed: 15291897]

20. Kenyon NJ, Last JA. Reversible and irreversible airway inflammation and fibrosis in mice exposed to inhaled ovalbumin. Inflamm Res 2005;54:57-65. [PubMed: 15750712]

21. Kilic FS, Erol K. The effects of vitamin E in ovalbumin-sensitized guinea pigs. Methods Find Exp Clin Pharmacol 2003;25:27-31. [PubMed: 12690703]

22. Bando N, Yamanishi R, Terao J. Inhibition of immunoglobulin E production in allergic model mice by supplementation with vitamin E and beta-carotene. Biosci Biotechnol Biochem 2003;67:21762182. [PubMed: 14586106]

23. Suchankova J, Voprsalova M, Kottova M, Semecky V, Visnovsky P. Effects of oral alpha-tocopherol on lung response in rat model of allergic asthma. Respirology 2006;11:414-421. [PubMed: 16771910] 
24. Talati M, Meyrick B, Peebles RS Jr, Davies SS, Dworski R, Mernaugh R, Mitchell D, Boothby M, Roberts LJ 2nd, Sheller JR. Oxidant stress modulates murine allergic airway responses. Free Radic Biol Med 2006;40:1210-1219. [PubMed: 16545689]

25. Meydani SN, Leka LS, Fine BC, Dallal GE, Keusch GT, Singh MF, Hamer DH. Vitamin E and respiratory tract infections in elderly nursing home residents: a randomized controlled trial. JAMA 2004;292:828-836. [PubMed: 15315997]

26. Meydani SN, Han SN, Wu D. Vitamin E and immune response in the aged: molecular mechanisms and clinical implications. Immunol Rev 2005;205:269-284. [PubMed: 15882360]

27. Fogarty A, Lewis S, Weiss S, Britton J. Dietary vitamin E, IgE concentrations, and atopy. Lancet 2000;356:1573-1574. [PubMed: 11075775]

28. Traber MG, Burton GW, Hamilton RL. Vitamin E trafficking. Ann NY Acad Sci 2004;1031:1-12. [PubMed: 15753129]

29. Schock BC, Van der Vliet A, Corbacho AM, Leonard SW, Finkelstein E, Valacchi G, ObermuellerJevic U, Cross CE, Traber MG. Enhanced inflammatory responses in alpha-tocopherol transfer protein null mice. Arch Biochem Biophys 2004;423:162-169. [PubMed: 14871478]

30. Lim Y, Vasu VT, Gohil K, Corbacho AM, Aung HH, Valacchi G, Traber MG, Kenyon NJ, Cross $\mathrm{CE}$. Role of vitamin $\mathrm{E}$ in allergic responses induced by inhaled ovalbumin exposure in $\alpha$-tocopherol transfer protein (TTP) null mice. FASEB J 2005;9:A443.

31. Terasawa Y, Ladha Z, Leonard SW, Morrow JD, Newland D, Sanan D, Packer L, Traber MG, Farese RV Jr. Increased atherosclerosis in hyperlipidemic mice deficient in alpha-tocopherol transfer protein and vitamin E. Proc Natl Acad Sci USA 2000;97:13830-13834. [PubMed: 11095717]

32. Kenyon NJ, Ward RW, Last JA. Airway fibrosis in a mouse model of airway inflammation. Toxicol Appl Pharmacol 2003;186:90-100. [PubMed: 12639500]

33. Podda M, Weber C, Traber MG, Packer L. Simultaneous determination of tissue tocopherols, tocotrienols, ubiquinols, and ubiquinones. J Lipid Res 1996;37:893-901. [PubMed: 8732789]

34. Hamada K, Goldsmith CA, Goldman A, Kobzik L. Resistance of very young mice to inhaled allergen sensitization is overcome by coexposure to an air-pollutant aerosol. Am J Respir Crit Care Med 2000;161:1285-1293. [PubMed: 10764325]

35. Suzuki YJ, Packer L. Inhibition of NF-kappa B activation by vitamin E derivatives. Biochem Biophys Res Commun 1993;193:277-283. [PubMed: 8503918]

36. Morante M, Sandoval J, Gomez-Cabrera MC, Rodriguez JL, Pallardo FV, Vina JR, Torres L, Barber T. Vitamin E deficiency induces liver nuclear factor-kappaB DNA-binding activity and changes in related genes. Free Radic Res 2005;39:1127-1138. [PubMed: 16298738]

37. Hybertson BM, Chung JH, Fini MA, Lee YM, Allard JD, Hansen BN, Cho OJ, Shibao GN, Repine JE. Aerosol-administered alpha-tocopherol attenuates lung inflammation in rats given lipopolysaccharide intratracheally. Exp Lung Res 2005;31:283-294. [PubMed: 15962709]

38. Wu D, Liu L, Meydani M, Meydani SN. Vitamin E increases production of vasodilator prostanoids in human aortic endothelial cells through opposing effects on cyclooxygenase- 2 and phospholipase A2. J Nutr 2005;135:1847-1853. [PubMed: 16046707]

39. Khanna S, Roy S, Ryu H, Bahadduri P, Swaan PW, Ratan RR, Sen CK. Molecular basis of vitamin E action: tocotrienol modulates 12-lipoxygenase, a key mediator of glutamate-induced neurodegeneration. J Biol Chem 2003;278:43508-43515. [PubMed: 12917400]

40. Gueck T, Aschenbach JR, Fuhrmann H. Influence of vitamin E on mast cell mediator release. Vet Dermatol 2002;13:301-305. [PubMed: 12464062]

41. Kempna P, Reiter E, Arock M, Azzi A, Zingg JM. Inhibition of HMC-1 mast cell proliferation by vitamin E: involvement of the protein kinase B pathway. J Biol Chem 2004;279:50700-50709. [PubMed: 15385541]

42. Li-Weber M, Giaisi M, Treiber MK, Krammer PH. Vitamin E inhibits IL-4 gene expression in peripheral blood T cells. Eur J Immunol 2002;32:2401-2408. [PubMed: 12207324]

43. Han SN, Adolfsson O, Lee CK, Prolla TA, Ordovas J, Meydani SN. Age and vitamin E-induced changes in gene expression profiles of T cells. J Immunol 2006;177:6052-6061. [PubMed: 17056531]

44. Mahabir S, Frenkel K, Brady MS, Coit D, Leibes L, Karkoszka J, Berwick M. Randomized, placebocontrolled pilot trial of the effects of alpha-tocopherol supplementation on levels of autoantibodies 
against 5-hydroxymethyl-2-deoxyuridine in melanoma patients. Melanoma Res 2004;14:49-56. [PubMed: 15091194]

45. Schramm CM, Puddington L, Wu C, Guernsey L, Gharaee-Kermani M, Phan SH, Thrall RS. Chronic inhaled ovalbumin exposure induces antigen-dependent but not antigen-specific inhalational tolerance in a murine model of allergic airway disease. Am J Pathol 2004;164:295-304. [PubMed: 14695342]

46. Davis BJ, Flanagan BF, Gilfillan AM, Metcalfe DD, Coleman JW. Nitric oxide inhibits IgE-dependent cytokine production and Fos and Jun activation in mast cells. J Immunol 2004;173:6914-6920. [PubMed: 15557187]

47. Borish L, Chipps B, Deniz Y, Gujrathi S, Zheng B, Dolan CM. Total serum IgE levels in a large cohort of patients with severe or difficult-to-treat asthma. Ann Allergy Asthma Immunol 2005;95:247-253. [PubMed: 16200815]

48. Ahmed T, Marko M, Wu D, Chung H, Huber B, Meydani SN. Vitamin E supplementation reverses the age-associated decrease in effective immune synapse formation in CD4+ T cells. Ann NY Acad Sci 2004;1031:412-414. [PubMed: 15753183]

49. Wegner CD, Gundel RH, Reilly P, Haynes N, Letts LG, Rothlein R. Intercellular adhesion molecule-1 (ICAM-1) in the pathogenesis of asthma. Science 1990;247:456-459. [PubMed: 1967851]

50. Lampinen M, Carlson M, Hakansson LD, Venge P. Cytokine-regulated accumulation of eosinophils in inflammatory disease. Allergy 2004;59:793-805. [PubMed: 15230810]

51. Stirling RG, van Rensen EL, Barnes PJ, Chung KF. Interleukin-5 induces CD34(+) eosinophil progenitor mobilization and eosinophil CCR3 expression in asthma. Am J Respir Crit Care Med 2001;164:1403-1409. [PubMed: 11704586]

52. Oldhoff JM, Darsow U, Werfel T, Katzer K, Wulf A, Laifaoui J, Hijnen DJ, Plotz S, Knol EF, Kapp A, Bruijnzeel-Koomen CA, Ring J, de Bruin-Weller MS. Anti-IL-5 recombinant humanized monoclonal antibody (mepolizumab) for the treatment of atopic dermatitis. Allergy 2005;60:693696. [PubMed: 15813818]

53. Abe M, Hayashi Y, Murai A, Shibata K, Sakata N, Igarashi R, Katsuragi T, Tanaka K. Effects of inducible nitric oxide synthase inhibitors on asthma depending on administration schedule. Free Radic Biol Med 2006;40:1083-1095. [PubMed: 16540403]

54. Singh U, Devaraj S, Jialal I. Vitamin E, oxidative stress, and inflammation. Annu Rev Nutr 2005;25:151-174. [PubMed: 16011463]

55. Desideri G, Marinucci MC, Tomassoni G, Masci PG, Santucci A, Ferri C. Vitamin E supplementation reduces plasma vascular cell adhesion molecule-1 and von Willebrand factor levels and increases nitric oxide concentrations in hypercholesterolemic patients. J Clin Endocrinol Metab 2002;87:2940_ 2945. [PubMed: 12050277]

56. Tsoureli-Nikita E, Hercogova J, Lotti T, Menchini G. Evaluation of dietary intake of vitamin E in the treatment of atopic dermatitis: a study of the clinical course and evaluation of the immunoglobulin E serum levels. Int J Dermatol 2002;41:146-150. [PubMed: 12010339]

57. Shahar E, Hassoun G, Pollack S. Effect of vitamin E supplementation on the regular treatment of seasonal allergic rhinitis. Ann Allergy Asthma Immunol 2004;92:654-658. [PubMed: 15237767]

58. Wagner JG, Jiang Q, Harkema JR, Ames BN, Illek B, Roubey RA, Peden DB. Gamma-Tocopherol prevents airway eosinophilia and mucous cell hyperplasia in experimentally induced allergic rhinitis and asthma. Clin Exp Allergy. 2007

59. Wagner JG, Jiang Q, Harkema JR, Illek B, Patel DD, Ames BN, Peden DB. Ozone enhancement of lower airway allergic inflammation is prevented by [gamma]-tocopherol. Free Radic Biol Med 2007;43:1176-1188. [PubMed: 17854713]

60. Gajewska BU, Swirski FK, Alvarez D, Ritz SA, Goncharova S, Cundall M, Snider DP, Coyle AJ, Gutierrez-Ramos JC, Stampfli MR, Jordana M. Temporal-spatial analysis of the immune response in a murine model of ovalbumin-induced airways inflammation. Am J Respir Cell Mol Biol 2001;25:326-334. [PubMed: 11588010]

61. Mathrani VC, Kenyon NJ, Zeki A, Last JA. Mouse models of asthma: can they give us mechanistic insights into the role of nitric oxide? Curr Med Chem 2007;14:2204-2213. [PubMed: 17691958] 
62. Jiang Q, Elson-Schwab I, Courtemanche C, Ames BN. Gamma-tocopherol and its major metabolite, in contrast to alpha-tocopherol, inhibit cyclooxygenase activity in macrophages and epithelial cells. Proc Natl Acad Sci USA 2000;97:11494-11499. [PubMed: 11005841]

63. Jiang Q, Ames BN. Gamma-tocopherol, but not alpha-tocopherol, decreases proinflammatory eicosanoids and inflammation damage in rats. Faseb J 2003;17:816-822. [PubMed: 12724340]

64. Jaffar Z, Ferrini ME, Buford MC, Fitzgerald GA, Roberts K. Prostaglandin I2-IP signaling blocks allergic pulmonary inflammation by preventing recruitment of CD4+ Th2 cells into the airways in a mouse model of asthma. J Immunol 2007;179:6193-6203. [PubMed: 17947695]

65. Azzi A, Gysin R, Kempna P, Ricciarelli R, Villacorta L, Visarius T, Zingg JM. Regulation of gene and protein expression by vitamin E. Free Radic Res 2002;36(Suppl 2):30-35. 
A

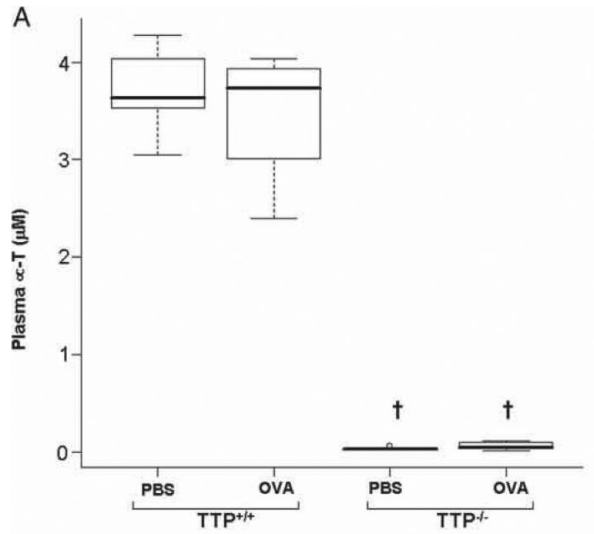

C

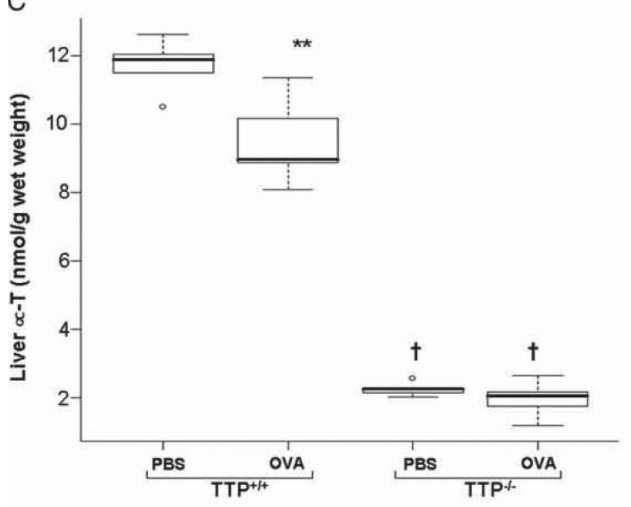

E

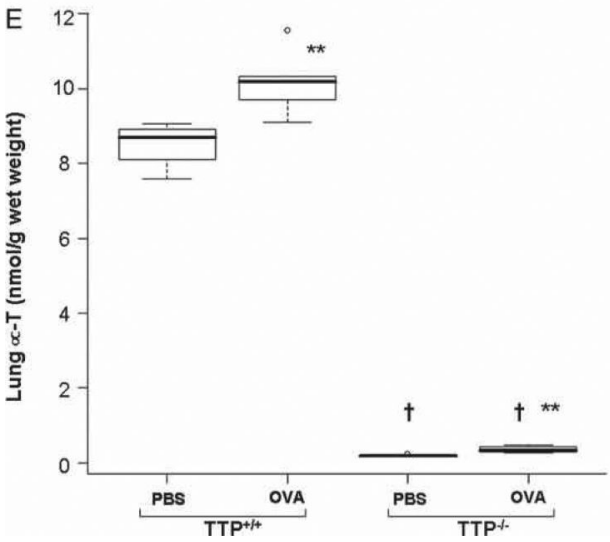

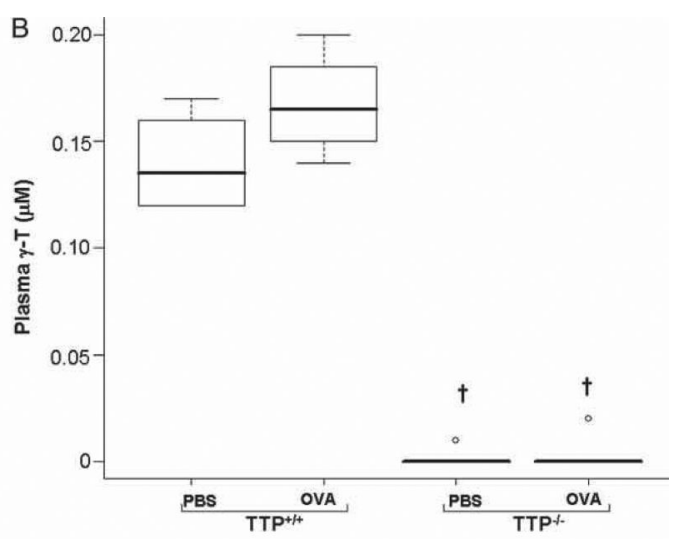

D
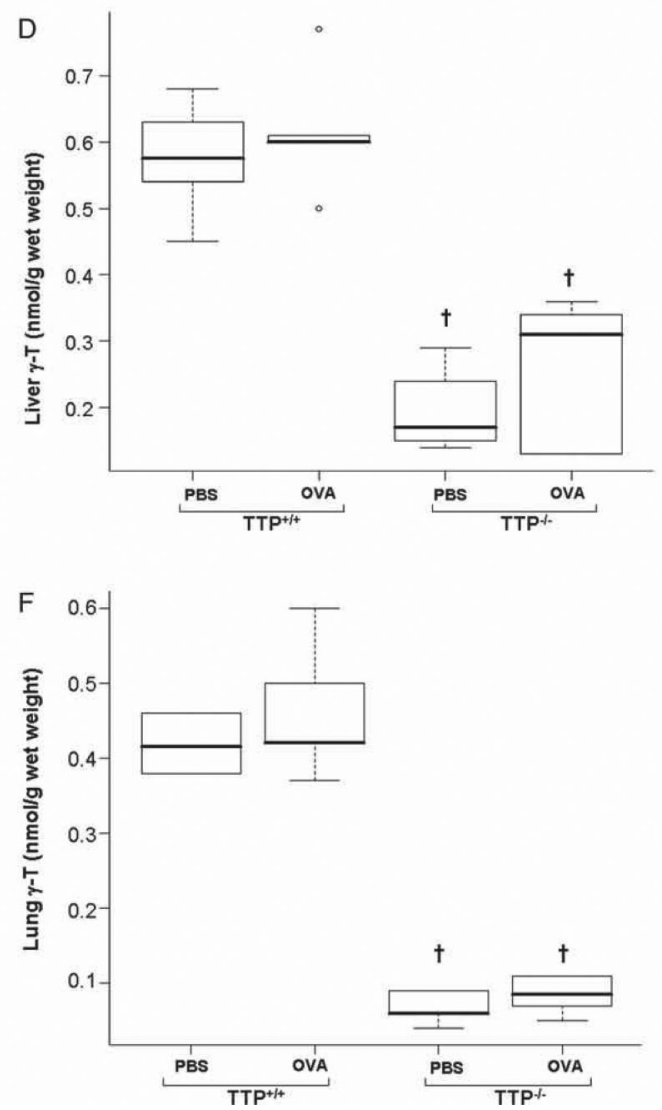

Figure 1.

$\alpha$-T and $\gamma$-T levels in plasma (A, B), liver (C, D) and lung (E, F) of $\mathrm{TTP}^{+/+}$and $\mathrm{TTP}^{-/-}$mice after PBS or OVA exposure. Values are mean $\pm \mathrm{SD}$ and median (minimum, maximum), $n=$ 6-5 per group. $\mathrm{TTP}^{-1-}$ mice have low Vitamin E tissue levels due to TTP gene deletion as compared to $\mathrm{TTP}^{+/+}$mice $(\dagger p<0.001)$. Liver $\alpha$-T levels were significantly decreased in OVA exposed $\mathrm{TTP}^{+/+}$mice as compared to respective PBS treated controls $(* * p<0.01)$. On the contrary, lung $\alpha$-T levels were significantly increased $(p<0.01)$ after OVA exposure in both the genotypes as compared to PBS treated controls. Plasma, liver and lung $\gamma$-T levels remained unchanged after OVA exposure. 

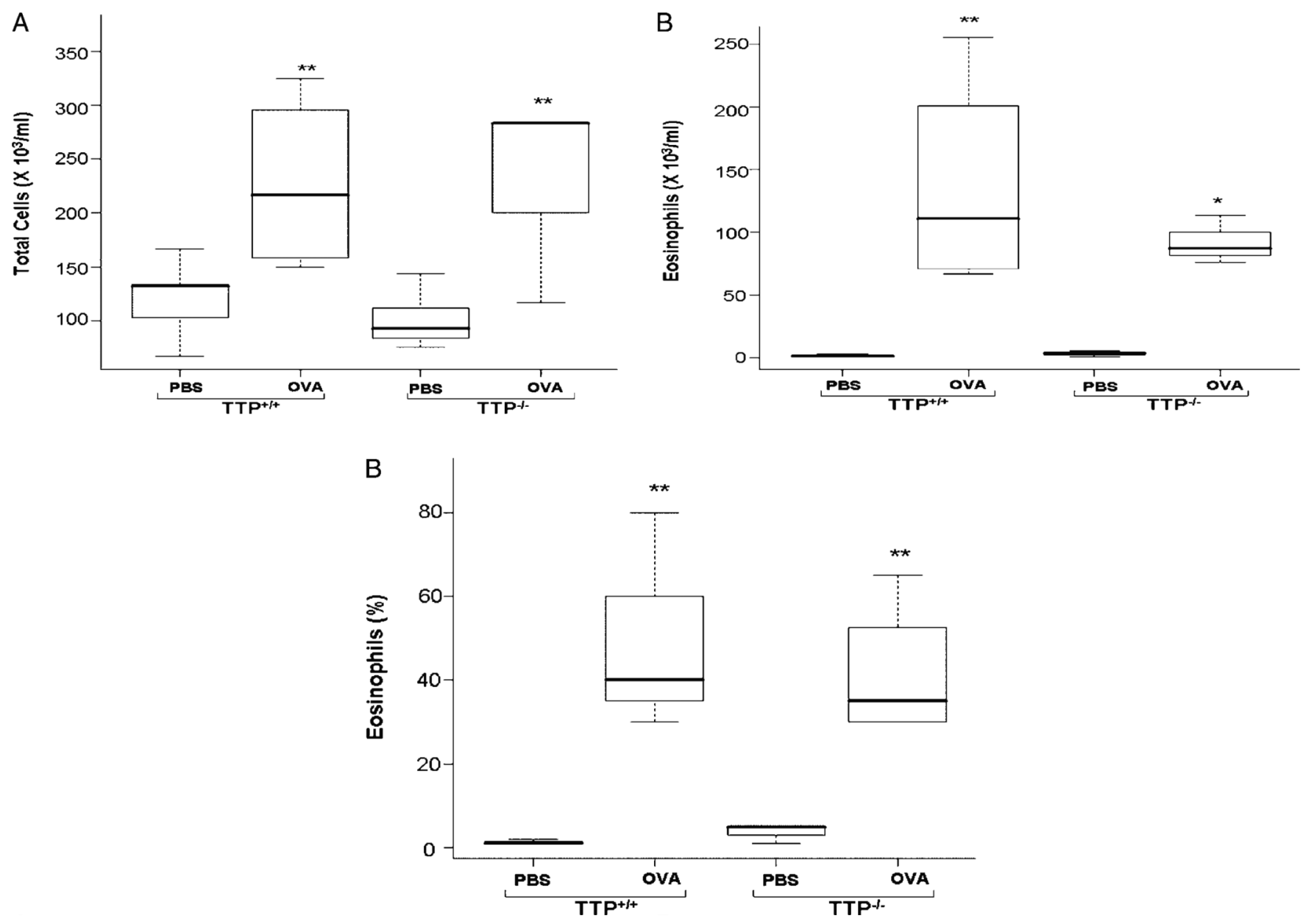

Figure 2.

Total number of cells (A), number of eosinophils (B) and\% of eosinophils (C) in BAL fluid of $\mathrm{TTP}^{+/+}$and $\mathrm{TTP}^{-/-}$mice after PBS or OVA exposure. Values are mean $\pm \mathrm{SD}$ and median (minimum, maximum), $n=6-5$ per group. As a result of OVA exposure, total BAL cells were significantly increased $(* * p<0.01)$ in both the genotypes as compared to respective PBS controls. Eosinophil cells in BAL fluid also showed a significant increase in OVA exposed $\mathrm{TTP}^{+/+}(* * p<0.01)$ and $\mathrm{TTP}^{-/-}(* p<0.05)$ mice as compared to PBS treated $\mathrm{TTP}^{+/+}$and $\mathrm{TTP}^{+/+}$controls. Similar trend was also seen in eosinophil percentage in BAL cells after OVA exposure $(* * p<0.01)$, but no significant differences were seen in both the genotypes in any of the parameters. 


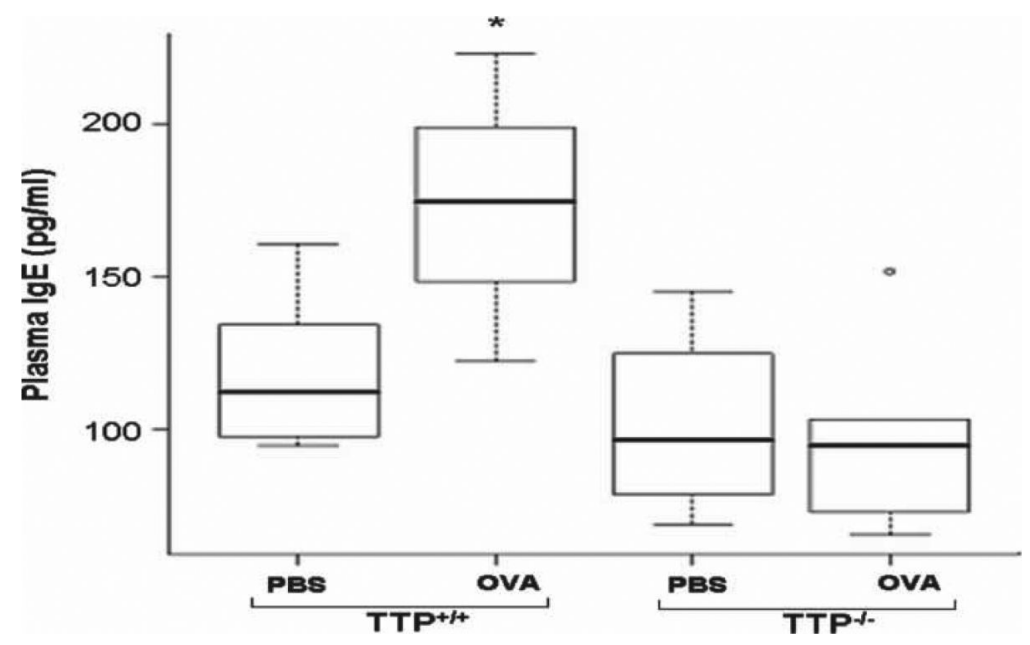

Figure 3.

Plasma IgE levels in $\mathrm{TTP}^{+/+}$and $\mathrm{TTP}^{-/-}$mice after PBS or OVA exposure. Values are mean $\pm \mathrm{SD}$ and median (minimum, maximum), $n=6-5$ per group. A significant increase in plasma IgE levels in $\mathrm{TTP}^{+/+}$mice $(* p<0.05$ ) was observed after OVA exposure as compared to PBS treated $\mathrm{TTP}^{+/+}$controls. There was no significant difference in OVA exposed $\mathrm{TTP}^{-/-}$mice or between the two genotypes. 

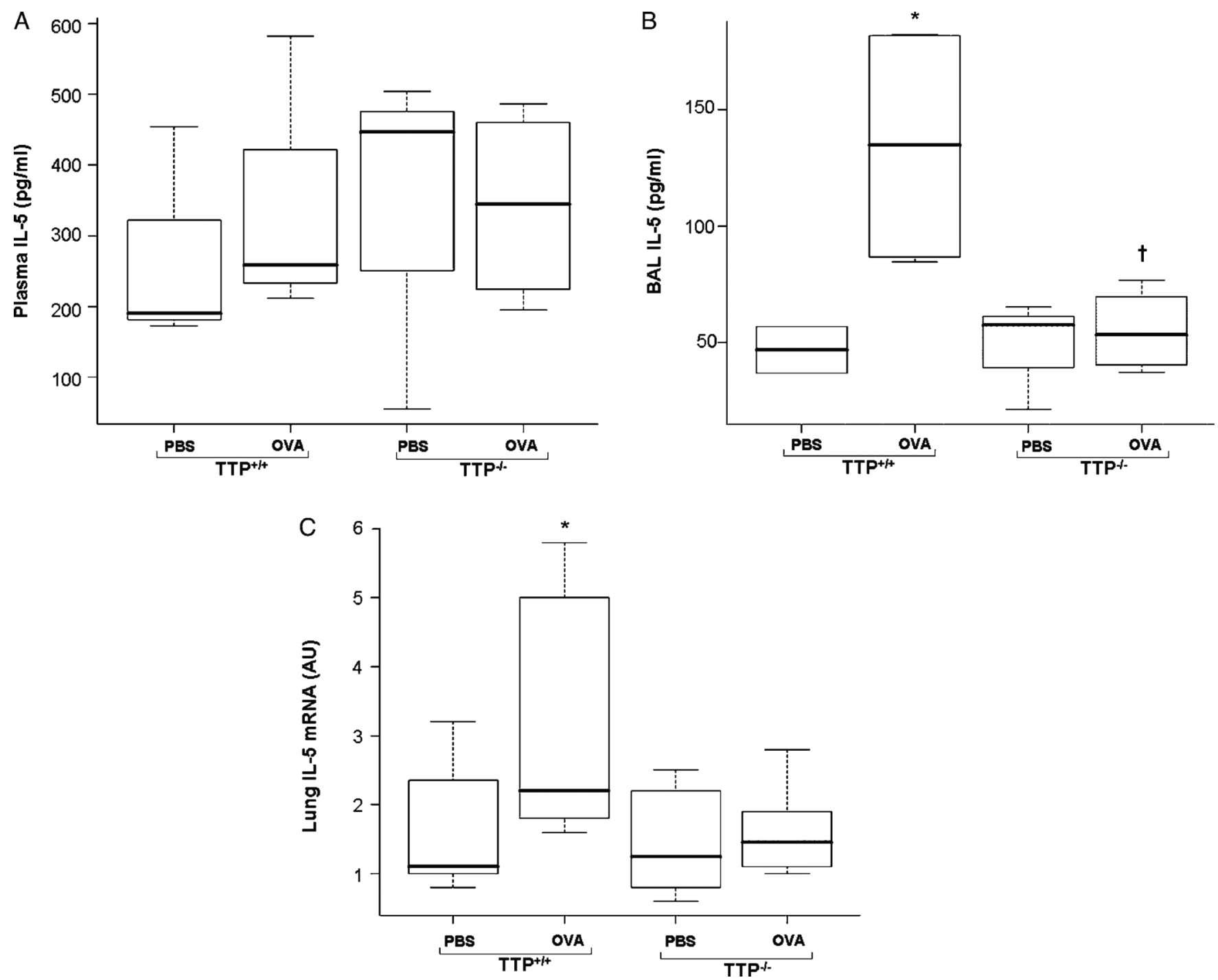

Figure 4.

IL-5 protein levels in plasma (A) and BALF (B) and mRNA expression levels in lung tissues (C) of $\mathrm{TTP}^{+/+}$and $\mathrm{TTP}^{-/-}$mice after PBS or OVA exposure. Values are mean $\pm \mathrm{SD}$ and median (minimum, maximum), $n=6-5$ per group. Plasma IL-5 protein levels were not significantly different irrespective of genotypes. BAL IL-5 protein levels and lung IL-5 mRNA expression were significantly increased $(* p<0.05)$ in $\mathrm{OVA}$ exposed $\mathrm{TTP}^{+/+}$mice as compared to PBS treated $\mathrm{TTP}^{+/+}$controls but no change were observed in $\mathrm{TTP}^{-/-}$mice. 


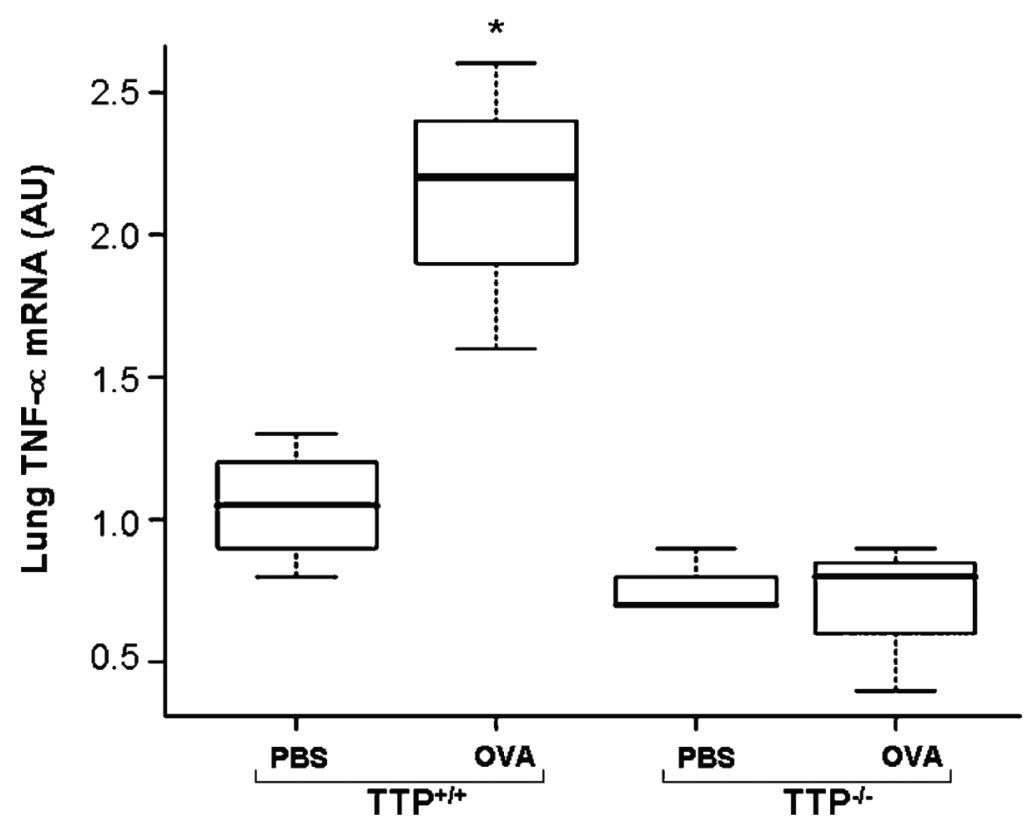

Figure 5.

TNF- $\alpha$ mRNA expression levels in lung tissues of $\mathrm{TTP}^{+/+}$and $\mathrm{TTP}^{-/-}$mice after PBS or OVA exposure. Values are mean $\pm \mathrm{SD}$ and median (minimum, maximum), $n=6-5$ per group. Lung tissues of $\mathrm{TTP}^{+/+}$mice exposed to OVA showed a significantly increased expression of TNF$\alpha$ mRNA $(* * p<0.05)$ as compared to PBS treated TTP $^{+/+}$controls. There was no significant difference in OVA exposed $\mathrm{TTP}^{-/}$mice or between the two genotypes. 

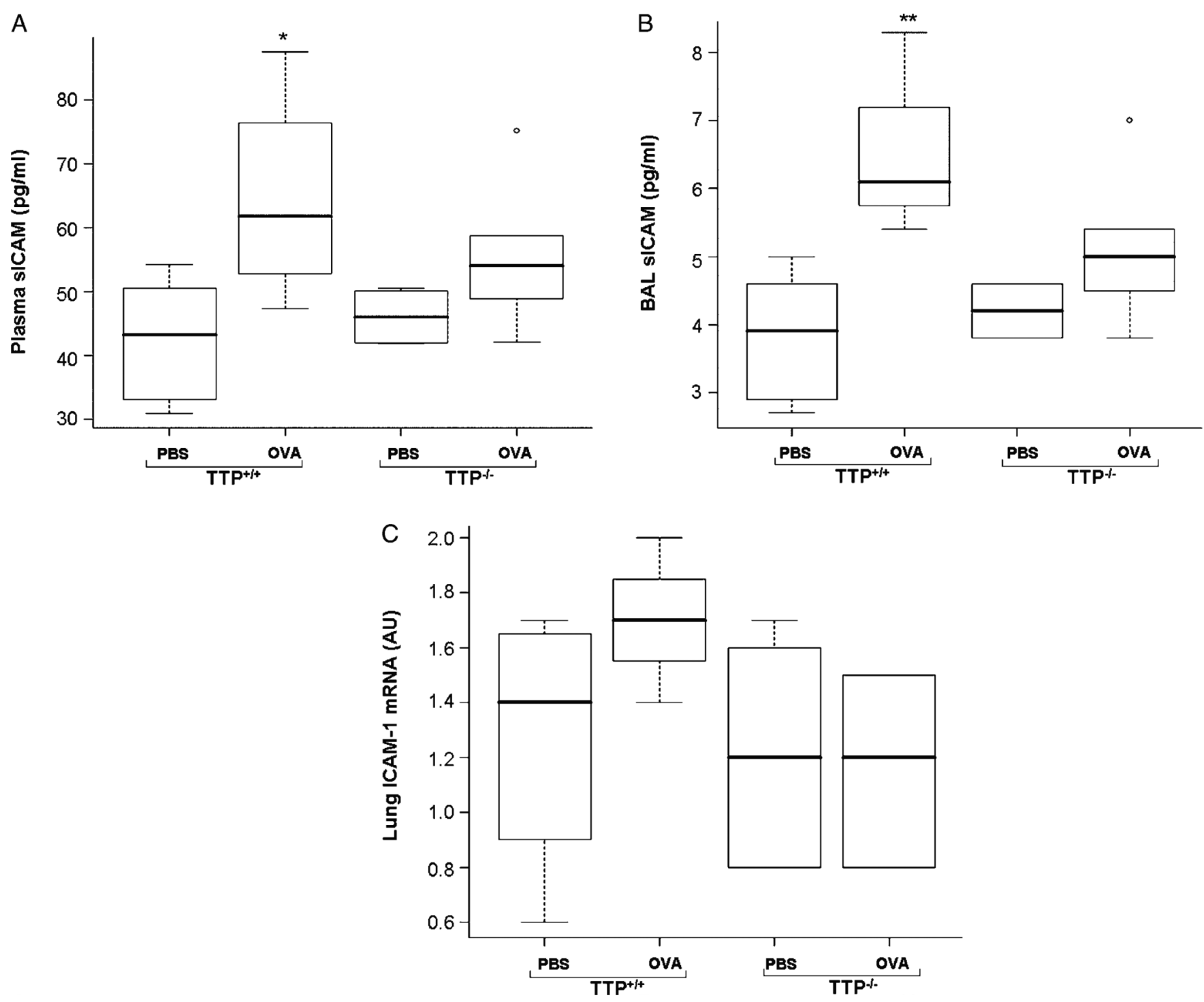

Figure 6.

sICAM protein levels in plasma (A) and BAL fluid (B) and ICAM-1 mRNA levels (C) in lung tissues of $\mathrm{TTP}^{+/+}$and $\mathrm{TTP}^{-/-}$mice after PBS or OVA exposure. Values are mean $\pm \mathrm{SD}$ and median (minimum, maximum), $n=6-5$ per group. Plasma and BAL sICAM levels were significantly increased $\left(* p<0.05, * * p<0.01\right.$, respectively) in $\mathrm{TTP}^{+/+}$mice after OVA exposure as compared to PBS treated $\mathrm{TTP}^{+/+}$controls. There was no significant difference in OVA exposed $\mathrm{TTP}^{-/-}$mice or between the two genotypes. The changes in lung mRNA ICAM expression was not statistically different in OVA treated $\mathrm{TTP}^{+/+}$or $\mathrm{TTP}^{-/-}$mice or between the two genotypes. 